UDC 517.9

\title{
Numerical simulation of electromagnetic wave diffraction on a finite number of slits in a flat screen
}

\author{
S.V. Zhuchenko \\ Kharkiv National University named after V.N. Karazin, Ukraine, Svobody square 4, Kharkiv, 61022, Ukraine \\ e-mail: stanislavzhuchenko@ukr.net
}

\begin{abstract}
The article presents an algorithm for modeling diffraction on slits made on a flat screen made of actual materials. As a result, the boundary conditions of Schukin-Leontovich lead to the mixed boundary value problem. According to the method of Y.V. Gandel and V.D. Dushkin the solution of the problem can be reduced to a system of paired integral equations with singular and logarithmic singularities. The author has created and debugged a PC program that performs the numerical solution of the arising problems, and a series of computational experiments has been performed. This work has been carried at School of Mathematics and Computer Sciences of V. N. Karazin Kharkiv National University within the state budget themes: "Modeling of the dynamics of folding systems with the method of identifying problem situations."
\end{abstract}

Key words: Sommerfeld radiation conditions, Meixner conditions, Fredholm integral equation of the second kind.

У статті видається алгоритм моделювання дифракції на щілинах проделаных в плоскому екрані виготовленому 3 реальних матеріалів. В результаті граничні умови Щукіна-Леонтовича призводять до третє крайового завдання. По методу проф. Ю.В. Ганделя і В.Д. Душкина рішення задачі зводиться до системи парних інтегральних рівнянь 3 сингулярною і логарифмічною особливостями. Створення програм ЕОМ що реалізовують подібні чисельні моделі надзвичайно актуально для впровадження передових комп'ютерних технологій в практику реальних фізичних досліджень. Автор статті останнім часом багато уваги приділяє створенню і відладці програм ЕОМ впроваджувальних в практику творчу спадщину проф. Ю.В. Ганделя. Зокрема в этой статті автор пропонує варіант програма ПЕВМ выполняющей чисельне рішення виникаючої задачі, а також з ії допомогою проводить серію обчислювальних експериментів. Ця програма може використовуватися для широкого дослідження процесів розсіяння і дифракції на подібних структурах, а також для верифікації аналогічних програм складених з використанням гіперсингулярних інтегралів, формули використовувані при створенні яких набагато складніше і вимагають ретельніших перевірок. Ця робота виконана на мехматі ХНУ ім. В.Н. Каразина у рамках держбюджетної тематики: "Моделювання динаміки складних систем з метою ідентифікації проблемних ситуацій"

Ключові слова : умови випромінювання Зоммерфельда, умови Майкснера, інтегральне рівняння Фредгольма другого роду, інтегральне рівняння ядром Коши $і$ з логарифмічною особливістю система лінійних рівнянь алгебри.

В статье представляется алгоритм моделирования дифракции на щелях проделаных в плоском экране изготовленном из реальных материалов. В результате граничные условия Щукина-Леонтовича приводят к третьей краевой задаче. По методу проф. Ю.В. Ганделя и В.Д. Душкина решение задачи сводится к системе парных интегральных уравнений с сингулярной и логарифмической особенностями. Автором составлена и отлажена программа ПЭВМ выполняющая численное решение возникающих задач, проводится серия вычислительных экспериментов. Создание программ ПЭВМ, которые реализуют подобные численные модели, чрезвычайно актуально для внедрения передовых компьютерных технологий в практику реальных физических исследований. Автор статьи в последнее время много внимания уделяет созданию и отладке программ ПЭВМ внедряющих в практику творческое наследство проф. Ю.В. Ганделя. Эта программа может использоваться для исследования процессов рассеяния и дифракции на подобных структурах, а также для верификации аналогичных программ составленных с использованием гиперсингулярных интегралов, формулы, которые используются при их создании намного сложнее и требуют более тщательных проверок..Данная работа выполнена на мехмате ХНУ им. В.Н. Каразина в рамках госбюджетной тематики: «Моделювання динаміки складних систем з метою ідентифікації проблемних ситуацій».

Ключевые слова: условия излучения Зоммерфельда, условия Майкснера, интегральное уравнение Фредгольма второго рода.

\section{Introduction}

One way of describing the interaction of electromagnetic waves with non PEC structures is to consider boundary-value problems for the Helmholtz equation with mixed boundary conditions [1] - [5]. Mixed conditions are consequences of Schukin-Leontovich boundary conditions (IBC). In [6]; [7], the systems of boundary integral equations for the problem of determining the direction of electromagnetic waves on an impedance tape were obtained. The method of parametric representations of integral transformations has been used to obtain these systems [8] - [10]. The numerical solution of these systems had been found by the method of discrete singularities [11]; [12]. This approach is widely used in modeling the scattering of electromagnetic waves on PEC structures [12] - [22].

The PC program created, debugged and used for the numerical modeling is based on the methods of solving diffraction problems developed by Y.V. Gandel and his students. In particular, the monography [12] in section 5.3 proposes a method for the numerical problem of diffraction of an electromagnetic 
wave by a finite number of slits on a flat screen made of actual materials. The article is devoted to the numerical solution of this problem. The results of some computational experiments obtained by using the developed program are presented at the end of the article.

\section{Arrangement and the method of solving the problem}

There is flat panel in subspace $\mathrm{z}=0$ with $\mathrm{M}$ slits which are parallel to the axis 0x. Fig. 1 shows the section of this screen by the YOZ subspace.

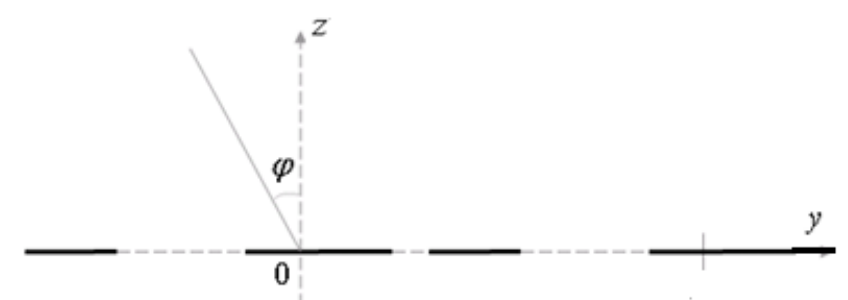

Fig. 1 Sectional drawing of the diffraction structure by the subspace YOZ

Let

$$
\mathrm{L}=\left\{\mathrm{y} \in \mathrm{R} \mid y \in \bigcup_{\mathrm{q}=1}^{M}\left(\alpha_{q}, \beta_{q}\right), 0<\alpha_{1}<\beta_{1}<\ldots<\alpha_{q}<\beta_{q}\right\},
$$

where $\mathrm{Y}$ - the coordinates of metal-free points.

Let us set $\Omega^{+}$and $\Omega^{-}$half-subspaces above and below the structure.

The flat electromagnetic wave of unit amplitude falls obliquely from infinity to the diffractive structure with the following $\mathrm{x}$-coordinate:

$$
u^{*}(y, z)=\exp (i k(y \cdot \sin \varphi-z \cdot \cos \varphi))
$$

It is necessary to find the full field resulting from the diffraction of a wave on a structure.

Let $u_{0}(y, z)$ be the field that is a result of diffraction of a given plane wave, when in the $\mathrm{z}=0$ plane a solid conductive screen is present. Due to the boundary conditions of Shchukin-Leontovich, the equality on the screen is:

$$
\frac{\partial u_{0}(y, 0)}{\partial z} h u_{0}(y, 0)=0, \quad y \in R
$$

The field $u_{0}(y, z)$ has the form:

$$
u_{0}(y, z)=\exp (i k(y \cdot \sin \varphi-z \cdot \cos \varphi))+\frac{i k \cos \varphi+h}{i k \cos \varphi-h} \exp \{i k(y \cdot \sin \varphi+z \cdot \cos \varphi)\},
$$

and the property:

$$
u_{0}(y, 0)=\frac{2 i k \cos \varphi}{i k \cos \varphi-h} \cdot \exp \{i k(y \cdot \sin \varphi)\}
$$

The full field $u(y, z)$, arising from the diffraction of a wave on a structure can be derived in the form:

$$
u(y, z)= \begin{cases}u_{0}(y, z)+u^{+}(y, z), & (y, z) \in \Omega^{+} ; \\ u^{-}(y, z), & (y, z) \in \Omega^{-} .\end{cases}
$$

The field $u^{+}(y, z)$ in the area $\Omega^{+}$is derived as:

$$
u^{+}(y, z)=\int_{-\infty}^{\infty} C^{+}(\lambda) \cdot \exp (i \lambda y-\gamma(\lambda) z) d \lambda, \quad,
$$

and in the area $\Omega^{-} u^{-}(y, z)$ is derived as: 


$$
\begin{gathered}
u^{-}(y, z)=\int_{-\infty}^{\infty} C^{-}(\lambda) \cdot \exp (i \lambda y+\gamma(\lambda) z) d \lambda, \\
\text { where } \gamma(\lambda)=\sqrt{\lambda^{2}-k^{2}}, \quad \operatorname{Re}(\gamma(\lambda)) \geq 0, \quad \operatorname{Im}(\gamma(\lambda)) \leq 0, \quad \lambda \in R .
\end{gathered}
$$

From the boundary conditions of Schukin-Leontovich on the surface of the screen follows that:

$$
\begin{aligned}
& \frac{\partial u^{+}}{\partial z}(y, 0)-h u^{+}(y, 0)=0, \quad y \in C L \\
& \frac{\partial u^{-}}{\partial z}(y, 0)+h u^{-}(y, 0)=0, \quad y \in C L
\end{aligned}
$$

The consequence of the continuity of the field and its derivatives in the screen slits are:

$$
\begin{gathered}
u_{0}(y, 0)+u^{+}(y, 0)=u^{-}(y, 0), \quad y \in L ; \\
\frac{\partial u_{0}}{\partial z}(y, 0)+\frac{\partial u^{+}}{\partial z}(y, 0)=\frac{\partial u^{-}}{\partial z}(y, 0), \quad y \in L ;
\end{gathered}
$$

From the boundary conditions (10), (11) and the conjugation conditions (12), (13), taking into account the representations of the fields (7) and (8) follows that:

$$
\begin{gathered}
\int_{-\infty}^{\infty}[\gamma(\lambda)+h] \cdot C^{+}(\lambda) \cdot \exp (i \lambda y) d \lambda=\int_{-\infty}^{\infty}[\gamma(\lambda)+h] \cdot C^{-}(\lambda) \cdot \exp (i \lambda y) d \lambda=0, \quad y \in C L \\
u_{0}(y, 0)-\int_{-\infty}^{\infty} C^{+}(\lambda) \cdot \exp (i \lambda y) d \lambda=\int_{-\infty}^{\infty} C^{-}(\lambda) \cdot \exp (i \lambda y) d \lambda, \quad y \in L \\
\frac{\partial u_{0}}{\partial z}(y, 0)-\int_{-\infty}^{\infty} C^{+}(\lambda) \cdot \gamma(\lambda) \exp (i \lambda y) d \lambda=\int_{-\infty}^{\infty} C^{-}(\lambda) \cdot \gamma(\lambda) \exp (i \lambda y) d \lambda, \quad y \in L
\end{gathered}
$$

Let:

$$
\begin{gathered}
F^{+}(y)=\frac{\partial u^{+}}{\partial z}(y, 0)-h u^{+}(y, 0)=\int_{-\infty}^{\infty} C^{+}(\lambda) \cdot[\gamma(\lambda)+h] \exp (i \lambda y) d \lambda \\
F^{-}(y)=\frac{\partial u^{-}}{\partial z}(y, 0)+h u^{-}(y, 0)=\int_{-\infty}^{\infty} C^{-}(\lambda) \cdot[\gamma(\lambda)+h] \exp (i \lambda y) d \lambda
\end{gathered}
$$

By (10), (11) the functions $F^{+}(y)$ and $F^{-}(y)$ have the properties:

$$
F^{+}(y)=0, \quad F^{-}(y)=0, \quad y \in C L .
$$

Using the definition and properties of the functions $F^{+}(y)$ and $F^{-}(y)$, for the functions $C^{+}(\lambda)$ and $C^{-}(\lambda)$ we obtain the integral representations:

$$
\begin{array}{cc}
C^{+}(\lambda)=-\frac{1}{2 \pi[\gamma(\lambda)+h]_{L}} \int_{L} F^{+}(t) \cdot e^{-i \lambda t} d t, & \lambda \in R ; \\
C^{-}(\lambda)=\frac{1}{2 \pi[\gamma(\lambda)+h]} \int_{L} F^{-}(t) \cdot e^{-i \lambda t} d t, \quad \lambda \in R .
\end{array}
$$

Considering (20), (21) for functions $u^{+}(y, 0)$ and $u^{-}(y, 0)$ we get integral representations:

$$
\begin{aligned}
& u^{+}(y, 0)=\int_{-\infty}^{\infty} C^{+}(\lambda) \cdot \exp (i \lambda y) d \lambda=-\frac{1}{2 \pi} \int_{L} F^{+}(t) d t \int_{-\infty}^{\infty} \frac{\exp (i \lambda(y-t))}{\gamma(\lambda)+h} d \lambda= \\
& =-\frac{1}{\pi} \int_{L}^{\infty} \int_{0}^{\infty} \frac{\cos (\lambda(y-t))}{\gamma(\lambda)+h} F^{+}(t) d t=-\frac{1}{\pi} \int_{L} F^{+}(t)\left[\int_{0}^{\infty} \frac{\cos (\lambda(y-t))}{\gamma(\lambda)} d \lambda-h \int_{0}^{\infty} \frac{\cos (\lambda(y-t))}{\gamma(\lambda) \cdot(\gamma(\lambda)+h)} d \lambda\right] d t
\end{aligned}
$$




$$
\begin{aligned}
& u^{-}(y, 0)=\int_{-\infty}^{\infty} C^{-}(\lambda) \cdot \exp (i \lambda y) d \lambda=\frac{1}{2 \pi} \int_{L} F^{-}(t) d t \int_{-\infty}^{\infty} \frac{\exp (i \lambda(y-t))}{\gamma(\lambda)+h} d \lambda= \\
& =-\frac{1}{\pi} \int_{L} F^{-}(t)\left[\int_{0}^{\infty} \frac{\cos (\lambda(y-t))}{\gamma(\lambda)} d \lambda-h \int_{0}^{\infty} \frac{\cos (\lambda(y-t))}{\gamma(\lambda) \cdot(\gamma(\lambda)+h)} d \lambda\right] d t
\end{aligned}
$$

It is known that

$$
\int_{0}^{\infty} \frac{\cos (\lambda(y-t))}{\gamma(\lambda)} d \lambda=\frac{i \pi}{2} H_{0}^{1}(k|y-t|)
$$

where $H_{0}^{1}(y)=J_{0}(y)+i \cdot N_{0}(y)-$ Hankel function of the first kind of zero order.

Considering (17), (18) we get:

$$
\begin{gathered}
u^{+}(y, 0)=\int_{-\infty}^{\infty} C^{+}(\lambda) \cdot \exp (i \lambda y) d \lambda=-\left[\frac{1}{\pi} \int_{L} \frac{i \pi}{2} H_{0}^{1}(k|y-t|) F^{+}(t) d t+\frac{1}{\pi} \int_{L} Q(y, t) F^{+} d t\right], \\
u^{-}(y, 0)=\int_{-\infty}^{\infty} C^{-}(\lambda) \cdot \exp (i \lambda y) d \lambda=\left[\frac{1}{\pi} \int_{L} \frac{i \pi}{2} H_{0}^{1}(k|y-t|) F^{-}(t) d t+\frac{1}{\pi} \int_{L} Q(y, t) F^{-} d t\right],
\end{gathered}
$$

where

$$
Q(y, t)=-h \int_{0}^{\infty} \frac{\cos (\lambda(y-t))}{\gamma(\lambda) \cdot(\gamma(\lambda)+h)} d \lambda
$$

For the convenience of further transformations we introduce the functions:

$$
\Lambda^{+}(t)=\left[F^{+}(t)+F^{-}(t)\right], \quad \Lambda^{-}(t)=\left[F^{+}(t)-F^{-}(t)\right], \quad t \in R .
$$

After substituting the integral representations (25), (26) for the functions $u^{+}(y, 0)$ and $u^{-}(y, 0)$ the conjugation condition (12), we obtain an integral equation of the first kind with a logarithmic singularity:

$$
\frac{1}{\pi} \int_{L} \frac{i \pi}{2} H_{0}^{1}(k|y-t|) \Lambda^{+}(t) d t+\frac{1}{\pi} \int_{L} Q(y, t) \Lambda^{+} d t=u_{0}(y, 0), \quad y \in L
$$

From (17), (18), (25), (26) for the function $\frac{\partial u^{+}}{\partial z}(y, 0)$, we obtain the integral representation:

$$
\begin{aligned}
& \frac{\partial u^{+}}{\partial z}(y, 0)=-\int_{-\infty}^{\infty} C^{+}(\lambda) \cdot \gamma(\lambda) \exp (i \lambda y) d \lambda=-\int_{-\infty}^{\infty} C^{+}(\lambda) \cdot[\gamma(\lambda)+h] \exp (i \lambda y) d \lambda+ \\
& \quad+h \int_{-\infty}^{\infty} C^{+}(\lambda) \cdot \exp (i \lambda y) d \lambda=F^{+}(y)-h\left[\frac{1}{\pi} \int_{L}^{i \pi} \frac{i}{2} H_{0}^{1}(k|y-t|) F^{+}(t) d t+\frac{1}{\pi} \int_{L} Q(y, t) F^{+} d t\right] .
\end{aligned}
$$

Similarly, for the function $\frac{\partial u^{-}}{\partial z}(y, 0)$, we obtain, using (18), (26), the integral representation:

$$
\begin{aligned}
& \frac{\partial u^{-}}{\partial z}(y, 0)=\int_{-\infty}^{\infty} C^{-}(\lambda) \cdot \gamma(\lambda) \exp (i \lambda y) d \lambda=\int_{-\infty}^{\infty} C^{-}(\lambda) \cdot[\gamma(\lambda)+h] \exp (i \lambda y) d \lambda- \\
& \quad-h \int_{-\infty}^{\infty} C^{-}(\lambda) \cdot \exp (i \lambda y) d \lambda=F^{-}(y)-h\left[\frac{1}{\pi} \int_{L} \frac{i \pi}{2} H_{0}^{1}(k|y-t|) F^{-}(t) d t+\frac{1}{\pi} \int_{L} Q(y, t) F^{-} d t\right] .
\end{aligned}
$$

After substituting the integral representations (30), (31) for the functions $\frac{\partial u^{+}}{\partial z}(y, 0)$ and $\frac{\partial u^{-}}{\partial z}(y, 0)$ into the conjugation condition (13), we obtain the Fredholm integral equation of the second kind:

$$
\Lambda^{-}(y)-h\left[\frac{1}{\pi} \int_{L} \frac{i \pi}{2} H_{0}^{1}(k|y-t|) \Lambda^{-}(t) d t+\frac{1}{\pi} \int_{L} Q(y, t) \Lambda^{-} d t\right]=-\frac{\partial u_{0}}{\partial z}(y, 0), \quad y \in L .
$$


Meixner conditions will be fulfilled if we look for restrictions of functions $\Lambda^{+}(y)$ and $\Lambda^{-}(y)$ at intervals $\left(\alpha_{q}, \beta_{q}\right)$ in the form:

$$
\begin{aligned}
& \Lambda^{+}(y)=\frac{V_{q}^{+}(y)}{\sqrt{\left(y-\alpha_{q}\right)\left(\beta_{q}-y\right)}}, \quad y \in\left(\alpha_{q}, \beta_{q}\right), \quad(q=1, \ldots, M) ; \\
& \Lambda^{-}(y)=\frac{V_{q}^{-}(y)}{\sqrt{\left(y-\alpha_{q}\right)\left(\beta_{q}-y\right)}}, \quad y \in\left(\alpha_{q}, \beta_{q}\right), \quad(q=1, \ldots, M) ;
\end{aligned}
$$

where $V_{q}^{+}(y) \in C\left[\alpha_{q}, \beta_{q}\right], \quad V_{q}^{-}(y) \in C\left[\alpha_{q}, \beta_{q}\right], \quad(q=1, \ldots, M)$.

Let:

$$
g_{q}:[-1,1] \rightarrow\left[\alpha_{q}, \beta_{q}\right], \quad g_{q}(t)=\frac{\beta_{q}-\alpha_{q}}{2} \tau+\frac{\beta_{q}+\alpha_{q}}{2}, \quad(q=1, \ldots, M)
$$

From this point the following notation will be used:

$$
\begin{gathered}
f^{-}(y)=-\frac{\partial u_{0}}{\partial z}(y, 0) \\
f_{1}^{+}(y)=-u_{0}(y, 0) \\
K_{1, q, p}^{+}(\xi, \tau)=-\frac{i \pi}{2} H_{0}^{1}\left(k\left|g_{q}(\xi)-g_{p}(\tau)\right|\right)-\delta_{q, p} \ln |\tau-\xi|-Q\left(g_{q}(\xi), g_{p}(\tau) \mid\right), \\
(q=1, \ldots, M), \quad(p=1, \ldots, M) ; \\
K_{q, p}^{-}(\xi, \tau)=h\left[\frac{i \pi}{2} H_{0}^{1}\left(k\left|g_{q}(\xi)-g_{p}(\tau)\right|\right)-\delta_{q, p} \ln |\tau-\xi|-Q\left(\left|g_{q}(\xi), g_{p}(\tau)\right|\right)\right] \\
(q=1, \ldots, M), \quad(p=1, \ldots, M) ;
\end{gathered}
$$

From (32) and taking into account (33) - (39), we obtain a system of integral equations with a logarithmic singularity on the standard interval $(-1,1)$.

$$
\begin{gathered}
\frac{2}{\beta_{q}-\alpha_{q}} \frac{V_{q}^{-}(\xi)}{\sqrt{1-\xi^{2}}}+\frac{h}{\pi} \int_{-1}^{1} \ln |\tau-\xi| \frac{V_{q}^{-}(\tau) d \tau}{\sqrt{1-\tau^{2}}}+ \\
+\frac{1}{\pi} \sum_{p=1}^{M} \int_{-1}^{1} K_{q, p}^{-}(\xi, \tau) \frac{V_{p}^{-}(\tau) d \tau}{\sqrt{1-\tau^{2}}}=f^{-}\left(g_{q}(\xi)\right), \quad|\xi| \leq 1, \quad(q=1, \ldots, M) .
\end{gathered}
$$

Taking into account (33) - (39), we transform the integral equation (29) to a system of integral equations of the first kind with a logarithmic singularity on the standard interval $(-1,1)$ :

$$
\frac{1}{\pi} \int_{-1}^{1} \ln |\tau-\xi| \frac{V_{q}^{+}(\tau) d \tau}{\sqrt{1-\tau^{2}}}+\frac{1}{\pi} \sum_{p=1}^{M} \int_{-1}^{1} K_{1, q, p}^{+}(\xi, \tau) \frac{V_{p}^{+}(\tau) d \tau}{\sqrt{1-\tau^{2}}}=f_{1}^{+}\left(g_{q}(\xi)\right), \quad|\xi| \leq 1, \quad(q=1, \ldots, M) .
$$

Let us use the notation:

$$
\begin{aligned}
K_{2, q, p}^{+}(\xi, \tau)=-\frac{1}{g_{q}^{\prime}(\xi)} \cdot \frac{\partial K_{1, q, p}^{+}(\xi, \tau)}{\partial \xi}= & -\frac{i k \pi}{2} H_{1}^{1}\left(k\left|g_{q}(\xi)-g_{p}(\tau)\right|\right)- \\
& -\frac{\delta_{q, p}}{g_{q}(\xi)-g_{q}(\tau)}+\frac{1}{g_{q}^{\prime}(\xi)} \frac{\partial}{\partial \xi} Q\left(\left|g_{q}(\xi), g_{p}(\tau)\right|\right),
\end{aligned}
$$




$$
f_{2}^{+}(y)=\frac{\partial u_{0}}{\partial z}(y, 0)
$$

The system of integral equations with a logarithmic singularity (41) is equivalent to the SIE system:

$$
\begin{gathered}
\frac{1}{\pi} \int_{-1}^{1} \frac{1}{g_{q}(\tau)-g_{q}(\xi)} \frac{V_{q}^{+}(\tau) d \tau}{\sqrt{1-\tau^{2}}}+\frac{1}{\pi} \sum_{p=1}^{M} \int_{-1}^{1} K_{2, q, p}^{+}(\xi, \tau) \frac{V_{p}^{+}(\tau) d \tau}{\sqrt{1-\tau^{2}}}=f_{2}^{+}\left(g_{q}(\xi)\right), \\
|\xi| \leq 1, \quad(q=1, \ldots, M)
\end{gathered}
$$

with additional conditions:

$$
\frac{1}{\pi} \int_{-1}^{1} \ln |\tau-\xi| \frac{V_{q}^{+}(\tau) d \tau}{\sqrt{1-\tau^{2}}}+\frac{1}{\pi} \sum_{p=1}^{M} \int_{-1}^{1} K_{1, q, p}^{+}(\xi, \tau) \frac{V_{p}^{+}(\tau) d \tau}{\sqrt{1-\tau^{2}}}=f_{1}^{+}\left(g_{q}(\xi)\right), \quad(q=1, \ldots, M) .
$$

Thus, the solution of the problem is reduced to solving a system of integral equations with a logarithmic singularity (40) and the SIE system (44) with Cauchy kernel and with additional conditions (45), also having a logarithmic feature, on the standard interval $(-1,1)$. It is assumed that the functions $\left\{g_{q}(\xi), f^{-}\left(g_{q}(\xi)\right), f_{1}^{+}\left(g_{q}(\xi)\right), f_{2}^{+}\left(g_{q}(\xi)\right), K_{q, p}^{-}(\xi, \tau), K_{1, q, p}^{+}(\xi, \tau), K_{2, q, p}^{+}(\xi, \tau)\right\} \in C_{[-1,1]}^{1, \gamma}$ for each of the variables are uniform with respect to the other variable. Here $C_{[-1,1]}^{1, \gamma}-$ the class of functions continuously differentiable on the interval $[-1,1]$, whose derivative satisfies the Hölder condition with the exponent $0<\gamma \leq 1$.

Let's proceed to the task (40):

We will look for approximate solutions of the SIE systems in (40) and (44), (45) as a vector of function $\left(V_{1, n_{1}}(\tau), \ldots, V_{q, n_{q}}(\tau), \ldots, V_{M, n_{M}}(\tau)\right)$, each q-th coordinate of which is the Lagrange interpolation polynomial function $V_{q}(\tau)$ of the degree $\left(n_{q}-1\right)$ over nodes $t_{k}^{n_{q}}, \quad\left(k=1, \ldots, n_{q}\right)$, that is, by the roots of the Chebyshev polynomial of the first kind.

Using Lagrange type 1 interpolation polynomials: $l_{n-1, k}^{1}(t)=\frac{T_{n}(t)}{T_{n}^{\prime}\left(t_{k}^{n}\right)\left(t-t_{k}^{n}\right)}, \quad k=1, \ldots, n \quad$ and Lagrange type 2 polynomials:

$l_{n-2, j}^{2}(t)=\frac{U_{n-1}(t)}{U_{n-1}^{\prime}\left(t_{0 j}^{n}\right)\left(t-t_{0 j}^{n}\right)}, \quad j=1, \ldots, n-1$

we approximate the smooth kernel of the equation (40)

$K_{q, p}^{-}(\xi, \tau) \approx \sum_{j=1}^{n_{q}-1} \sum_{k=1}^{n_{p}} K_{q, p}^{-}\left(t_{0 j}^{n}, t_{k}^{n}\right) \cdot l_{n_{p}-1}^{1}(\tau) \cdot l_{n_{q}-2}^{2}(\xi)=K_{q, p, n_{q}-2, n_{p}-1}^{-}(\xi, \tau)$.

$T_{n}(t)$ and $U_{n-1}(t)$ are Chebyshev polynomials of the first and second kind, respectively. After that, to approximate the integral with a smooth kernel in (40), we use the well-known quadrature formula [12]:

$$
\frac{1}{\pi} \int_{-1}^{1} K_{q, p}^{-}(\xi, \tau) \frac{V_{p}^{-}(\tau) d \tau}{\sqrt{1-\tau^{2}}} \approx \frac{1}{n_{p}} \sum_{k=1}^{n_{p}} K_{q, p, n_{q}-2, n_{p}-1}^{-}\left(\xi, t_{k}^{n_{p}}\right) \cdot V_{p, n_{p}}\left(t_{k}^{n_{p}}\right) .
$$

For integrals with a logarithmic kernel, we use the formula [12]:

$$
\frac{1}{\pi} \int_{-1}^{1} \ln |\tau-\xi| \frac{V_{q}^{+}(\tau) d \tau}{\sqrt{1-\tau^{2}}}=-\frac{1}{n_{q}} \sum_{k=1}^{n_{q}} V_{q, n_{q}}\left(t_{k}^{n_{q}}\right)\left[\ln 2+2 \sum_{l=1}^{n_{q}-1} T_{l}(\xi) \cdot \frac{T_{l}\left(t_{k}^{n_{q}}\right)}{l}\right]
$$


Substituting the right-hand sides of the quadrature formulas (46) and (47) into the integral equation (40) and giving similar terms with respect to the unknown values of the vector functions in all nodes $t_{k}^{n_{p}}, \quad(p=1, \ldots, M), \quad\left(k=1, \ldots, n_{p}\right), \quad$ we obtain a linear algebraic equation for these unknowns (note in (47) $\mathrm{p}=\mathrm{q}$ ). The coefficients of these equations are functions which depend on $\xi$. Sequentially substituting in all these functions instead $\xi$ the values of all nodes $t_{l}^{n_{q}}, \quad(q=1, \ldots, M), \quad\left(l=1, \ldots, n_{q}\right)$, we obtain $\sum_{q=1}^{M} n_{q}$ of linear algebraic equations for the same number of unknowns. The solutions of this system are substituted into vector function $\left(V_{1, n_{1}}(\tau), \ldots, V_{q, n_{q}}(\tau), \ldots, V_{M, n_{M}}(\tau)\right)$ presenting the solutions of equation (40).

To solve the system of integral equations (44) and (45) for smooth kernels and kernels with a logarithmic singularity, we use the same quadrature formulas (46) and (47). For the integral with the Cauchy kernel in equation (44), the quadrature formula [12] is used:

$$
\frac{1}{\pi} \int_{-1}^{1} \frac{1}{g_{q}(\tau)-g_{q}(\xi)} \frac{V_{q}^{+}(\tau) d \tau}{\sqrt{1-\tau^{2}}}=\frac{1}{n_{q}} \sum_{k=1}^{n_{q}} \frac{V_{q, n_{q}}\left(t_{k}^{n_{q}}\right)}{g_{q}\left(t_{k}^{n_{q}}\right)-g_{q}(\xi)}
$$

Substituting the right-hand sides of quadrature formulas (46), (47) and (48) into integral equations (44) and carrying out similar terms with respect to the unknown values of the vector functions at all nodes $t_{k}^{n_{p}}, \quad(p=1, \ldots, M), \quad\left(k=1, \ldots, n_{p}\right), \quad$ we obtain a linear algebraic equation with respect to these unknowns. The coefficients of this equation are functions which depend on $\xi$. In contrast to the previous case, in order to obtain a system of linear algebraic equations, successively substituted into all functions of equation (44) not the $\xi$ values of all nodes $t_{l}^{n_{q}}, \quad(q=1, \ldots, M), \quad\left(l=1, \ldots, n_{q}\right)$, but the values $\xi$ of all nodes $t_{0 j}^{n_{q}}, \quad(q=1, \ldots, M), \quad\left(j=1, \ldots, n_{q}-1\right)$. As a result we obtain $\sum_{q=1}^{M}\left(n_{q}-1\right)$ of linear algebraic equations. It should be noted that $t_{0 j}^{n_{q}}$ are the roots of the Chebyshev polynomial of the second kind. M equations which are absent will be obtained using the integral equation (45). To do this, in the quadrature formula instead $\xi$ for each $q, \quad(q=1, \ldots, M)$ is substituted one arbitrary $t_{0 j}^{n_{q}}$. The solutions of this system are substituted in vector functions $\left(V_{1, n_{1}}(\tau), \ldots, V_{q, n_{q}}(\tau), \ldots, V_{M, n_{M}}(\tau)\right)$ presenting the solutions of equations (44) and (45).

\section{Results of computational experiments}

According to the method presented above, a PC program has been compiled and debugged. Below we present the results of calculations obtained with it.

As an example, we investigate a finite-dimensional analogue of the dependence of the functions $C^{+}(\lambda)$ on the dimensionless wavenumber $\mathrm{k}$. To establish such a relationship, we use the representations of these functions introduced in the previous section as integral transformations (20) and (21). Then, using expressions (28), (33) and (34), we obtain integral representations $C^{+}(\lambda)$ and $C^{-}(\lambda)$ from solutions of integral equations (40), (44) and (45):

$$
C^{+}(\lambda)=-\frac{1}{4 \pi[\gamma(\lambda)+h]} \int_{L} \frac{\left(V_{q}^{+}(y)+V_{q}^{-}(y)\right)}{\sqrt{\left(y-\alpha_{q}\right)\left(\beta_{q}-y\right)}} \cdot e^{-i \lambda t} d t, \quad(q=1, \ldots,), \lambda \in R ;
$$




$$
C^{-}(\lambda)=\frac{1}{4 \pi[\gamma(\lambda)+h]_{L}} \int_{L} \frac{\left(V_{q}^{+}(y)-V_{q}^{-}(y)\right)}{\sqrt{\left(y-\alpha_{q}\right)\left(\beta_{q}-y\right)}} \cdot e^{-i \lambda t} d t, \quad(q=1, \ldots,), \lambda \in R ;
$$

Then, using formula (35) for dimensionless variables and using quadrature formula (46) to calculate integrals with a smooth kernel, we obtain approximate formulas for calculating functions $C^{+}(\lambda)$ and $C^{-}(\lambda)$ for integer values $\lambda$ :

$$
\begin{aligned}
& C^{+}(n)=-\frac{1}{4[\gamma(n)+h]} \sum_{q=1}^{M} \frac{1}{n_{q}} \sum_{k=1}^{n_{q}}\left(V_{q, n_{q}}^{+}\left(t_{k}^{n_{q}}\right)+V_{q, n_{q}}^{-}\left(t_{k}^{n_{q}}\right)\right) \cdot e^{-\mathrm{in} g_{q}\left(t_{k}^{n_{q}}\right)}, \quad-N \leq n \leq N, \quad n \in Z ; \\
& C^{-}(n)=\frac{1}{4[\gamma(n)+h]} \sum_{q=1}^{M} \frac{1}{n_{q}} \sum_{k=1}^{n_{q}}\left(V_{q, n_{q}}^{+}\left(t_{k}^{n_{q}}\right)-V_{q, n_{q}}^{-}\left(t_{k}^{n_{q}}\right)\right) \cdot e^{-\mathrm{in} g_{q}\left(t_{k}^{n_{q}}\right)}, \quad-N \leq n \leq N, \quad n \in Z ;
\end{aligned}
$$

Fig. 2 presents the results of such calculations for the case when a plane electromagnetic wave of a single amplitude normally falls on a diffraction structure with a single slit. Y-coordinates of a slit are located on the segment $\left[\frac{\pi}{6}, \frac{5 \pi}{6}\right]$. Through $C_{n}^{ \pm}$the modules of each of the $\mathrm{n}$ harmonics are denoted, and
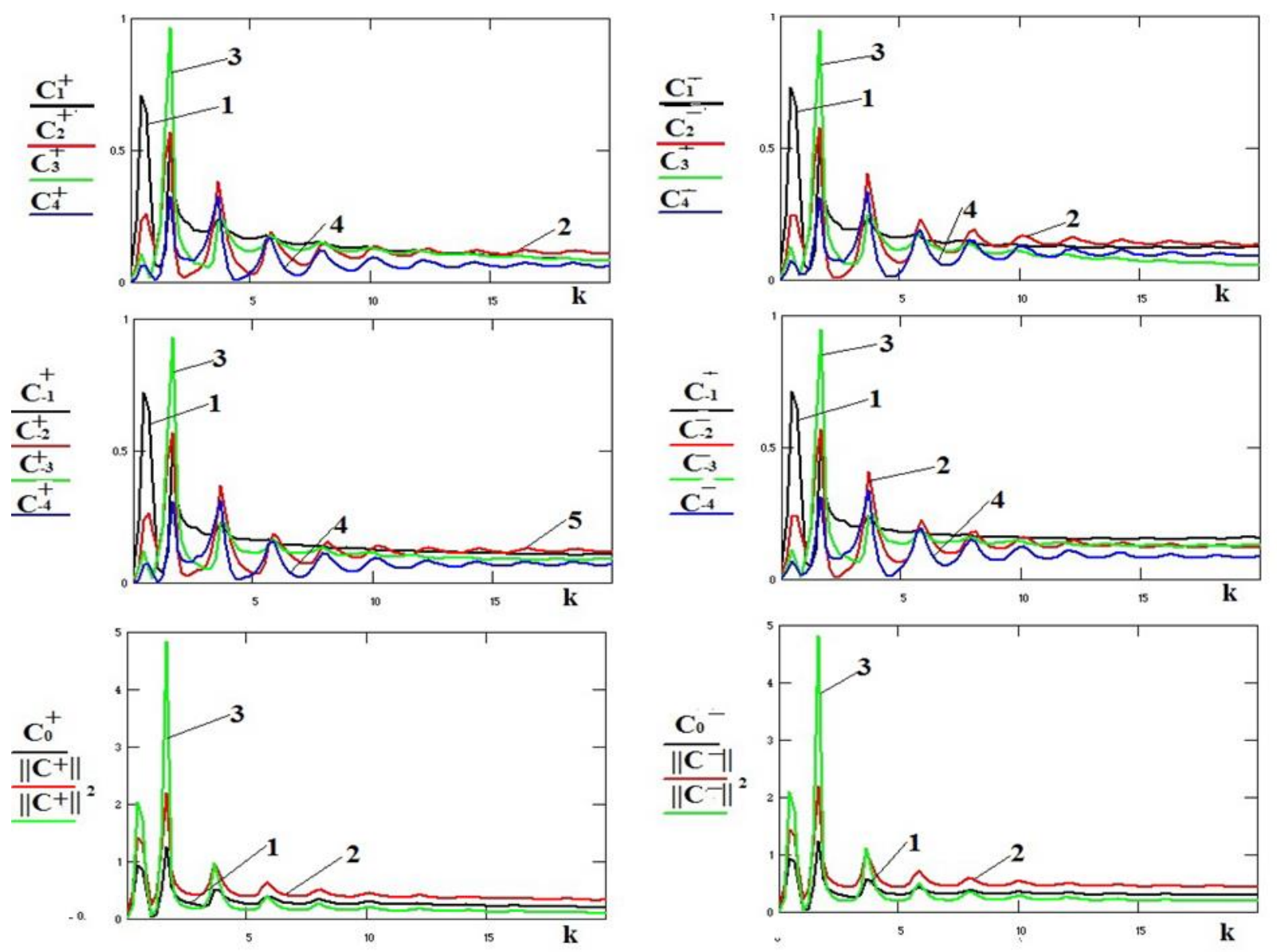

Fig.2 Dependencies of functions $C^{+}(\lambda)$ and $C^{-}(\lambda)$ on the dimensionless wavenumber $k$. Single slot structure 
$\|C\|$ is the total modulus of all the considered harmonics $C_{n}^{ \pm}=\sqrt{\operatorname{real}\left(C^{ \pm}(n)\right)^{2}+\operatorname{imag}\left(C^{ \pm}(n)\right)^{2}}$, $\|C\|=\sum_{n=-N}^{N} \sqrt{\operatorname{real}\left(C^{ \pm}(n)\right)^{2}+\operatorname{imag}\left(C^{ \pm}(n)\right)^{2}}$. In all experiments, the case of E-polarization is considered.

Fig. 3 presents similar graphs for the diffraction structure represented by two slits of different widths. Their y-coordinates are located on segments $\left[\frac{\pi}{6}, \frac{5 \pi}{6}\right]$ and $[2 \pi, 7 \pi]$. To the slit, which is considered in the first experiment, a slit of noticeably larger sizes is added. As expected, in comparison with Fig. 2, in Fig. 3, the previous peaks of the curves remained in place, but many new ones appeared. This indicates the growth of the diffraction radiation spectrum in the second experiment, in comparison with the first. The power of diffraction radiation also increases. This is especially evident when comparing the latest graphs in these figures. In the last two graphs of Fig. 3, and especially for small k, the graphs of the curves $C_{0}^{+}$and $C_{0}^{-}$coincide almost completely and that is why they are represented almost everywhere in red color. The same situation takes place for pairs of graphs $\left\|C^{+}\right\|,\left\|C^{-}\right\|$и $\left\|C^{+}\right\|^{2},\left\|C^{-}\right\|^{2}$.
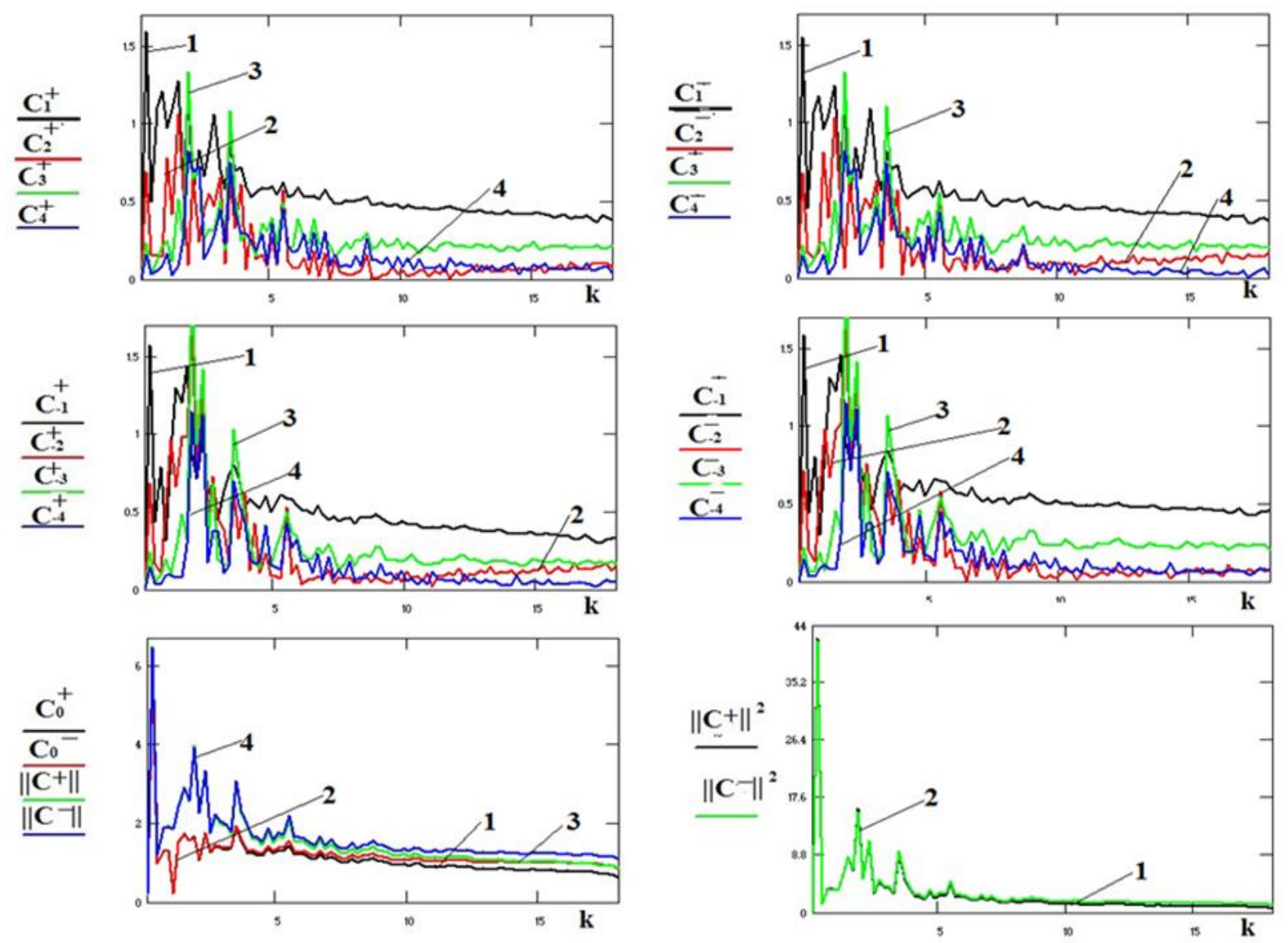

Fig.3. Dependencies of functions $C^{+}(\lambda)$ and $C^{-}(\lambda)$ on the dimensionless wavenumber $k$. The structure of two slits of different sizes 


\section{REFERENCES}

1. A. S. Il'insky, A. Ja. Slepjan, G. Ja. Slepjan, Propagation, diffraction and dissipation of electromagnetic waves. London (UK): The IEE and Peter Peregrinous Ltd., Electromagnetic Waves, Ser. 36. 275 p. 1993.

2. T. L. Zinenko, A. I. Nosich, "Wave Scattering and Absorption by Flat Gratings of Impedance Strips". IEEE Trans. Antennas and Propagation, vol. 54, No. 7, pp. 2088-2095, JULY 2006.

3. V. F. Kravchenko, The electrodynamics of superconducting structures. The theory, algorithms and computational methods: Moscow: Fizmatlit, 2006.

4. O. V. Kostenko, "Mathematical model of wave scattering by an impedance grating". Cybernetics and systems analysis, vol. 51, pp. 344-360, No. 3, 2015.

5. Yu. Penkin, V. Katrych, M. Nesterenko, S. Berdnik, "Coupling of Two Rectangular Waveguides Through a Slot With an Impedance Membrane," VII th International Conference on Mathematical Methods in ElectromagneticTheory. Kyiv, Ukraine 2 - 5, July 2018, pp. 140-143.

6. Yu. V. Gandel', V.F. Kravchenko, V.I. Pustovoit, "Scattering of electromagnetic waves by a thin superconducting band". Doklady Math. 1996. 54, No. 3. pp. 959-961.

7. Yu.V. Gandel, V.F. Kravchenko, N.N. Morozova, "Solving the problem of electromagnetic wave diffraction by a superconducting thin stripes grating," Telecommunications and Radio Engineering (English translation of Elektrosvyaz and Radiotekhnika),vol. 56, pp. 15-17, No.2, 2001.

8. N. I. Akhiezer, Lectures on integral transforms. Providence (R. I.): AMS, 1988.

9. Yu. V. Gandel', "Boundary-Value Problems for the Helmholtz Equation and their Discrete Mathematical Models". Journal of Mathematical Sciences, vol. 171, pp. 74-88. No.1, Springer Science+Business Media, Inc. 2010.

10. Y.V. Gandel, V.D. Dushkin, The method of parametric representations of integral and pseudodifferential operators in diffraction problems on electrodynamics structures: Proceedings of the International Conference Days on Diffraction DD 2012 (28 May-1 June 2012), St. Petersburg, 2012, pp.76-81.

11. I. K. Lifanov, Singular integral equations and discrete vortices. Utrecht (the Netherlands): VSP VB, 1996.

12. Yu.V. Gandel, V.D. Dushkin, Mathematical models of two-dimensional diffraction problems: Singular integral equations and numerical methods of discrete singularities method. Academy of IT of the MIA of Ukraine, Kharkiv, 2012. [in Russian]

13. Yu.V. Gandel', V.D. Dushkin, "Mathematical models based on SIE 2D diffraction problems on reflective multilayer periodic structures, Part I. The case of E-polarization, Scientific statements." Series: Mathematics. Physics. Belgorod State National Research University. vol. 5 (100), pp. 5-16, 2011.

14. V.A. Shcherbina, G.I. Zaginaylov, S.V. Zhuchenko, Numerical theory of excitation of axisymmetric open-ended finite length slow wave structure on the basis of the boundary singular integral equation method: VII th International Conference on Mathematical Methods in Electromagnetic Theory (MMET'98), Kharkov, Ukraine. vol. 1, 1998. pp. 263-265.

15. G.I. Zaginaylov, V.D. Dushkin, V. Korostyshevski, P.V. Turbin, Modeling the beam excitation of planar waveguide with rectangular irregularities: Proceedings of the VII th International Conference on Mathematical Methods in Electromagnetic Theory (MMET'98), Kharkov, Ukraine; 2 June 1998 through 5 June 1998; vol. 1, 1998, pp. 409-410.

16. Y.V. Gandel, V.D. Dushkin, G.I. Zaginaylov, "New numerical-analytical approach in the theory of excitation of super dimensional electro dynamical structures," Telecommunications and Radio Engineering (English translation of Elektrosvyaz and Radiotekhnika).vol. 54, 7, pp. 36-48, 2000.

17. S.V. Zhuchenko, Numerical model diffraction of the plane electromagnetic wave onto axially symmetric parabolic reflector: Bulletin of V. Karazin Kharkiv National University, Series "Mathematical Modelling. Information Technology. Automated Control Systems _Issue 22. No.1063, pp. 63-71, 2013. [in Russian]

18. V.D. Dushkin, "Mathematical models of two-dimensional diffraction problems," Proceedings of the VI th International Conference on Mathematical Methods in Electromagnetic Theory (MMET'96); Lviv, V.1, 1996. DOI:10.1109/MMET.1996.565767, pp. 483-486. 
19. V.S. Bulygin, A.I. Nosich, Y.V. Gandel, "Nystrom-type method in three dimensional electromagnetic diffraction by a finite PEC rotationally symmetric surface," IEEE Transactions on Antennas and Propagation. pp. 4710-4718, 60 (10), 2012.

20. S.V. Zhuchenko, "Discrete mathematical model of electromagnenic wave 3D diffraction on axially symmetric reflector," Bulletin of V. Karazin Kharkiv National University, Series "Mathematical Modelling. Information Technology. Automated Control Systems", Issue 23. No. 1089, pp. 50-68, 2013. [in Russian].

21. A. A. Nosich, Y. V. Gandel, "Numerical analysis of quasioptical multi-reflector antennas in 2-D with the method of discrete singularities," IEEE Transactions on Antennas and Propagation, vol. 57, pp. 399-406, no. 2, 2007.

22. S.V. Dukhopelnikov, "Inhomogeneities in the antenna cavity and the diffractive properties of antennas of a special form Numerical analysis." Part 1, Bulletin of V. Karazin Kharkiv National University, Series "Mathematical Modelling. Information Technology. Automated Control Systems". pp. 25-34, 32, 2016.

\section{ЛИТЕРАТУРА}

1. A. S. Il'insky, A. Ja. Slepjan, G. Ja. Slepjan, Propagation, diffraction and dissipation of electromagnetic waves. - London (UK): The IEE and Peter Peregrinous Ltd., 1993. Electromagnetic Waves, Ser. 36. 275 p.

2. T. L. Zinenko, A. I. Nosich, Wave Scattering and Absorption by Flat Gratings of Impedance Strips, IEEE Transactions on Antennas and Propagation. V. 54. No. 7. JULY 2006. P. 2088-2095.

3. V. F. Kravchenko, The electrodynamics of superconducting structures. The theory, algorithms and computational methods, Moscow: Fizmatlit, 2006. 280 p.

4. O. V. Kostenko, Mathematical model of wave scattering by an impedance grating, Cybernetics and systems analysis. V. 51, No. 3. 2015. P. 344-360.

5. Yu. Penkin, V. Katrych, M. Nesterenko, S. Berdnik, Coupling of Two Rectangular Waveguides Through a Slot With an Impedance Membrane, VII th International Conference on Mathematical Methods in ElectromagneticTheory. Kyiv. Ukraine 2 - 5. July 2018. P. 140-143.

6. Yu. V. Gandel', V.F. Kravchenko, V.I. Pustovoit, Scattering of electromagnetic waves by a thin superconducting band. Doklady Math. 1996. 54, No. 3. P. 959-961.

7. Yu.V. Gandel, V.F. Kravchenko, N.N. Morozova, Solving the problem of electromagnetic wave diffraction by a superconducting thin stripes grating, Telecommunications and Radio Engineering (English translation of Elektrosvyaz and Radiotekhnika). 2001. V. 56, No.2.-P. 15-17.

8. N. I. Akhiezer, Lectures on integral transforms. - Providence (R. I.): AMS, 1988. 108 p.

9. Yu. V. Gandel', Boundary-Value Problems for the Helmholtz Equation and their Discrete Mathematical Models. Journal of Mathematical Sciences. 2010. V. 171, No.1. Springer Science+Business Media, Inc. P. 74-88.

10. Y.V. Gandel, V.D. Dushkin, The method of parametric representations of integral and pseudodifferential operators in diffraction problems on electrodynamics structures. Proceedings of the International Conference Days on Diffraction DD 2012 (28 May-1 June 2012), St. Petersburg, 2012. P.76-81.

11. I. K. Lifanov, Singular integral equations and discrete vortices. Utrecht (the Netherlands): VSP VB, 1996. $475 \mathrm{p}$.

12. Гандель Ю. В., Душкин В. Д. Математические модели двумерных задач дифракции: Сингулярные интегральные уравнения и численные методы дискретных особенностей: монография. Х. : Акад. ВВ МВД Украины, 2012. 544c.

13. Гандель Ю.В., Душкин В.Д. Математические модели на основе СИУ 2D задач дифракции на многослойных периодических отражающих структурах. Часть I. Случай Е-поляризации. Научные ведомости Бел Гу Серия Математика. Физика. 2011. № 5(100). Вып. 22. С.5-16.

14. V.A. Shcherbina, G.I. Zaginaylov, S.V. Zhuchenko, Numerical theory of excitation of axisymmetric open-ended finite length slow wave structure on the basis of the boundary singular integral equation method. VII th International Conference on Mathematical Methods in Electromagnetic Theory (MMET'98), Kharkov, Ukraine. V. 1. 1998. P. 263-265.

15. G.I. Zaginaylov, V.D. Dushkin, V. Korostyshevski, P.V. Turbin, Modeling the beam excitation of planar waveguide with rectangular irregularities. Proceedings of the VII th International 
Conference on Mathematical Methods in Electromagnetic Theory (MMET'98. Kharkov. Ukraine. 2 June 1998 through 5 June 1998. V. 1. 1998. P. 409-410.

16. Y.V. Gandel, V.D. Dushkin, G.I. Zaginaylov, New numerical-analytical approach in the theory of excitation of superdimensional electrodynamical structures. Telecommunications and Radio Engineering (English translation of Elektrosvyaz and Radiotekhnika). 2000. V. 54, 7. P. 36-48.

17. Жученко С.В. Численная модель дифракции плоской электромагнитной волны на осесимметричном параболическом рефлекторе. Вестник Харьковского национального университета Серия "Математическое моделирование. Информационные технологии. Автоматизированные системы управления». №1063. вып. 22. 2013. с. 63-71.

18. V.D. Dushkin, Mathematical models of two-dimensional diffraction problems. Proceedings of the VI th International Conference on Mathematical Methods in Electromagnetic Theory (MMET'96). Lviv. V.1. 1996. P. 483-486. DOI:10.1109/MMET.1996.565767.

19. V.S. Bulygin, A.I. Nosich, Y.V. Gandel, Nystrom-type method in three dimensional electromagnetic diffraction by a finite PEC rotationally symmetric surface, IEEE Transactions on Antennas and Propagation. 60 (10). 2012. P. 4710-4718. [in Russian]

20. Жученко С.В. Дискретная математическая модель 3D дифракции электромагнитной волны на осесимметричном рефлекторе. Вестник Харьковского наи. Университета. Серия «Математическое моделирование, информационные технологии автоматизированых систем управления». № 1089. выпуск 23. 2013. С. 50-68.

21. A. A. Nosich, Y. V. Gandel, Numerical analysis of quasioptical multi-reflector antennas in 2-D with the method of discrete singularities. IEEE Transactions on Antennas and Propagation. 2007. V. 57, no. 2. P. 399-406.

22. S.V. Dukhopelnikov, Inhomogeneities in the antenna cavity and the diffractive properties of antennas of a special form Numerical analysis. Part 1, Bulletin of V. Karazin Kharkiv National University, Series "Mathematical Modelling. Information Technology. Automated Control Systems". 2016. 32. P. 25-34.

Zhuchenko Stanislav Vladimirovich - Candidate of Physical and Mathematical Sciences; Kharkiv National University named after V.N. Karazin, Kharkiv-22, Svoboda Square, 461022; e-mail: stanislavzhuchenko@ukr.net; ORCID.org/0000-0002-1946-7044.

Жученко Станислав Владимирович - кандидат физико-математических наук; Харьковский национальный университет имени В.Н. Каразина, Харьков-22, площадь Свободы, 4;61022; e-mail: stanislavzhuchenko@ukr.net; ORCID.org/0000-0002-1946-7044.

Жученко Станіслав Володимирович - кандидат фізико-математичних наук; Харківський начіональний університет імені В.Н. Каразіна, Харків-22, площа Свободи, 4; 61022;

e-mail: stanislavzhuchenko@ukr.net; ORCID.org/0000-0002-1946-7044. 